\title{
ANALISIS TEUN A. VAN DJIK \\ DALAM KAJIAN \\ WACANATEKS DAKWAH \\ DI MEDIA MASSA
}

\author{
Umi Halwati $^{*}$
}

\begin{abstract}
Mass media construct dakwah discourses in text forms. The texts of dakwah discourses in mass media need to be analyzed and discourse analysis can reveal the discourse of dakwah texts in mass media. The discourse analysis of Teun $A$. Van Diik covers: 1) text analysis, that is, how to analyze text structures by applying linguistic analysis to explain and get the meaning of a text; 2) social cognition analysis, that is how a text was created by the author; and 3) social analysis, that is how a text is related to social structure and knowledge of the society.
\end{abstract}

Keywords: Dakwah Discourse, Film, Amar Ma'ruf Nahi Munkar.

\section{PENDAHULUAN}

Wacana-wacana ke-Islaman dikonstruksi oleh media massa. Dalam itu, perang wacana dakwah tidak dapat dihindarkan. Perang wacana ini "tersusun" melalui berbagai media, termasuk media massa. Media massa merupakan alat atau mediator yang efektif dalam publikasi ideologi, baik ideologi pro maupun kontra. Menurut Eriyanto, ${ }^{1}$ teks merupakan salah satu bentuk praktik ideologi, bahasa, tulisan, pilihan kata maupun struktur gramatika dipahami sebagai pilihan yang diungkapkan membawa makna ideologi tertentu dalam taraf memenangkan dukungan publik.

Keberadaan produksi teks-teks media tentang wacana dakwah perlu dianalisis untuk membedah berbagai teks wacana dakwah di media massa. Pada kaitan ini, isi media dipengaruhi oleh berbagai komponen yang terdapat dalam institusi media itu sendiri. ${ }^{2}$

Ada tiga metode dalam membahas isi media dengan pendekatan kualitatif, yaitu analisis wacana (discourse analysis), analisis semiotik

\footnotetext{
•) Penulis adalah Dosen Jurusan Dakwah STAIN Purwokerto.
} 
(semiotic analysis), dan analisis framing (framing analysis). Semuanya berpijak pada asumsi bahwa isi media dipengaruhi oleh berbagai komponen yang terdapat dalam institusi media itu sendiri. ${ }^{3}$ Sobur ${ }^{4}$ menyatakan bahwa analisis wacana terhadap teks media diperlukan untuk mengetahui isi teks dan pesan yang disampaikan. Analisis wacana lebih melihat pada "upaya dari pesan atau teks komunikasi".

Analisis wacana atas isi teks menurut Van Djik (dalam Sobur ${ }^{5}$ ) juga menekankan bahwa wacana sebagai salah satu interaksi. Wacana dapat berfungsi sebagai suatu pernyataan (assertion), pertanyaan (question), tuduhan (accusastion) atau ancaman (threat). Wacana juga dapat digunakan untuk mendiskriminasi atau mempersuasi orang lain untuk melakukan diskriminasi.

Kelahiran teks jenis apapun, termasuk teks dakwah, tidak luput dari pengaruh sosial, ekonomi, politik dan budaya suatu tempat dan waktu. Teks atau ceramah keagamaan yang disampaikan ulama yang bersahabat dengan istana raja atau presiden, yang dimanjakan oleh harta dan fasilitas politik, pasti berbeda dari ceramah atau karya tulis yang lahir dari ulama yang kritis terhadap istana. Menurut Nurudin, ${ }^{6}$ penyampaian teks melalui saluran komunikasi massa mempunyai efek yang berwujud pada tiga hal, yaitu efek kognitif (pengetahuan), afektif (emosinal dan perasaan), dan behavioral (perubahan pada tingkah laku). Selain itu, muncul juga efek lain yang melatarbelakangi seperti individu yang bertolak dari gejala psikologi dan faktor sosial. Dari efek ini, muncul opini publik, yang biasanya tidak terorganisir serta menyebar pada berbagai tempat dan disatukan oleh isu tertentu melalui kontak satu sama lain, melalui media massa.

Dengan demikian, wacana dakwah adalah representasi budaya agama, yang terpetakan pada teks-teks dakwah dalam rangka merespons kondisikondisi sosial yang dihadapi seseorang atau sekelompok orang, baik dalam bentuk menyetujui, mendebat, menentang, maupun memberikan solusi permasalahan sosial, politik, ekonomi, dan budaya yang dihadapi masyarakat. Proses dakwah identik dengan proses produksi dan reproduksi wacana agama yang tidak lepas dari konteks sosio-budaya yang melingkupinya.

\section{HUBUNGAN DAKWAH DENGAN ANALISIS WACANA}

Wilayah dakwah meliputi semua aktivitas manusia secara total, baik secara individu sebagai abdi Tuhan, maupun sebagai anggota masyarakat, bahkan sebagai warga alam semesta. Wilayah dakwah bersinggungan 
dengan berbagai aspek kehidupan politik, sosial, ekonomi, budaya, dan sebagainya. Dengan kata lain, wilayah dakwah berada di perlintasan berbagai kepentingan manusia yang masing-masing memperjuangkan versinya masing-masing. Wilayah dakwah kadang juga merupakan arena pertarungan berbagai ideologi yang masing-masing mengklaim kebenarannya. Pada kaitan ini, proses produksi dan reproduksi wacana dakwah bukan berada pada ruang hampa yang bebas dari pengaruh ideologi lain.7

Dakwah merupakan usaha penyampaian ajaran Islam dalam rangka merespons kondisi dan permasalahan sosial, politik, ekonomi, maupun masalah budaya. Usaha penyampaian ajaran Islam tersebut diinterpretasikan dalam rangka merespons (menjawab, mendebat, menguatkan, menolak, dan sebagainya) permasalahan sosial, politik, ekonomi, maupun masalah budaya. Dakwah menjadi proses produksi dan reproduksi makna keagamaan dalam rangka merespons permasalahan tersebut. Kelahiran sebuah teks jenis apapun, termasuk teks keagamaan dan teks wacana dakwah, tidak luput dari pengaruh ekonomi politik yang melingkupinya. Oleh karena itu, dalam memahami dan menafsirkan teks, asumsi-asumsi kepentingan tersebut akan sangat besar pengaruhnya. ${ }^{8}$

Pesan dakwah adalah interpretasi da'i terhadap pokok-pokok ajaran agama (al-Qu'an dan al-Hadis) dalam rangka memecahkan permasalahan sosial yang dihadapi masyarakat. Hasil pikiran dan perilaku budaya yang menyangkut keagamaan disebut budaya agama. Menurut Mulyana, apa yang dibicarakan, bagaimana cara membicarakannya, apa yang dilihat, perhatikan, bagaimana berpikir dan apa yang dipikirkan dipengaruhi oleh budaya. 9

Setiap praktik komunikasi pada dasarnya adalah representasi budaya, sedangkan komunikasi dan budaya adalah dua entitas tak terpisahkan. Sebagaimana dikatakan Edward T, Hall, "Budaya adalah komunikasi, dan komunikasi adalah budaya". ${ }^{10}$ Bahasa merupakan peta yang menggambarkan budaya."

Pada perkembangannya, dakwah tidak lagi terbatas pada komunitas primitif, sederhana, eksotis, dan belum kenal teks tertulis yang batas-batas georafinya jelas. Perkembangan dakwah dewasa ini semakin terbuka dan terpengaruh arus kemajuan media massa.

Wacana apapun di media merupakan konstruksi yang bersifat ideologis. Hal itu memuat sejumlah kepentingan pihak-pihak tertentu, termasuk pengusaha media cetak dan praktisi pers. Teks-teks yang beredar di ruang publik merefleksikan adanya formasi-formasi diskursif. Konteks dari perbincangan itu ada di dalam ruang publik media massa. Media massa 
menjadi pasar komoditi yang memperdagangkan teks-teks sejajar dengan iklan-iklan produk komersial. Cara kerja media massa terletak pada soal komoditi, perdagangan, dan untung rugi. Oleh karena itu, media berusaha mengkonstruksi wacana.

Analisis wacana dari Teun A. Van Djik merupakan salah satu metode analisis teks media untuk membedah cara media mengkonstruksi wacana. Analisis wacana menekankan pada konstelasi kekuatan yang terjadi pada proses produksi dan reproduksi makna. Analisis wacana melihat pemakaian bahasa dalam tuturan dan tulisan sebagai praktik sosial. Bahasa dianalisis bukan menggambarkan semata dari aspek kebahasaan, tetapi juga menghubungkan konteks. Konteks di sini berarti bahasa dipakai untuk tujuan dan praktik tertentu.

Berkenaan dengan titik perhatian kajian yang terletak pada analisis wacana di media cetak, terdapat tiga hal penting yang saling berkaitan; teks, konteks dan wacana. ${ }^{12}$ Analisis wacana yang dimaksud di sini adalah mendeskripsikan teks dan konteks secara bersamaan dalam proses komunikasi. ${ }^{13}$

Dalam rangka pengembangan dakwah dan pemurnian aktivitas dakwah agar selalu berjalan pada garis yang diidealkan, maka analisis wacana terhadap wacana-wacana dakwah sangat diperlukan. Ciri khas dan konsentrasi dakwah adalah penyadaran, pemberdayaan, dan transformasi sosial. Tiga hal itu pula yang menjadi moral concern teori-teori wacana. Oleh karena itu, analisis wacana yang merupakan bagian studi kritis yang melihat produksi dan distribusi budaya, termasuk artefak budaya semacam teks. Hal itu juga relevan untuk studi teks-teks dakwah. ${ }^{14}$

\section{KONSEP ANALISIS WACANA}

\section{Pengertian Analisis Wacana}

Analisis wacana adalah salah satu alternatif dari analisis isi, selain analisis isi kuantitatif yang dominan dan banyak dipakai. Jika analisis isi kuantitatif lebih menekankan pada pertanyaan "apa” (what), maka analisis wacana lebih melihat pada "bagaimana" (how) dari pesan atau teks komunikasi. Melalui analisis wacana, tidak hanya mengetahui apa isi teks, tetapi juga cara pesan itu disampaikan lewat frase, kalimat, dan metafora.

Wacana sendiri adalah istilah yang dipakai oleh berbagai disiplin ilmu, mulai dari politik, sosiologi, linguistik, psikologi, komunikasi dan sebagainya. Setiap disiplin ilmu tersebut terkadang berbeda dalam konsep dan pendekatan yang dipakai. Definisi mengenai wacana ${ }^{15}$ antara lain: 
a. Collin Concise English Dictionary, 1999. Wacana adalah (1) komunikasi verbal, ucapan, percakapan; (2) sebuah perlakuan formal dari subjek dalam ucapan atau tulisan; dan (3) sebuah unit teks yang digunakan oleh linguis untuk menganalisis satuan lebih dari kalimat.

b. Roger Fowler, 1977. Wacana adalah komunikasi lisan atau tulisan yang dilihat dari titik pandang kepercayaan, nilai, dan kategori yang masuk di dalamnya. Kepercayaan di sini mewakili pandangan dunia, sebuah organisasi atau representasi dari pengalaman.

c. Foucault, 1972. Wacana kadangkala sebagai bidang dari semua pernyataan (statement), kadangkala sebagai sebuah individualisasi kelompok pernyataan dan kadangkala sebagai praktik regulatif yang dilihat dari sejumlah pernyataan.

d. Longman Dictionary of the English Language, 1984. (1) Sebuah percakapan khusus yang alamiah formal dan pengungkapannya diatur pada ide dalam ucapan dan tulisan. (2) pengungkapan dalam bentuk sebuah nasihat, risalah dan sebagainya, sebuah unit yang dihubungkan ucapan atau tulisan.

e. JS. Badudu, 2000. (1) Rentetan kalimat yang saling berkaitan, yang menghubungkan proposisi satu dengan proposisi yang lainnya membentuk satu kesatuan sehingga terbentuklah makna yang serasi di antara kalimat-kalimat itu. (2) kesatuan bahasa yang terlengkap dan tertinggi atau terbesar di atas kalimat atau klausa dengan koherensi dan kohesi yang tinggi serta berkesinambungan, yang mampu mempunyai awal dan akhir yang nyata, disampaikan secara lisan atau tertulis.

f. Crystal, 1987. Analisis wacana memfokuskan pada struktur yang secara alamiah terdapat pada bahasa lisan, sebagaimana banyak terdapat dalam wacana seperti percakapan, wawancara, komentar, dan ucapanucapan.

Adanya perbedaan mengenai wacana ini lebih dikarenakan adanya cara pandang yang berbeda dari disiplin ilmu yang melatarbelakanginya. ${ }^{16}$ Dalam lapangan sosiologi, wacana adalah unit bahasa yang lebih besar dari kalimat. Analisis wacana dalam studi linguistik merupakan reaksi dari bentuk linguistik formal yang lebih memperhatikan pada unit kata, frasa atau kalimat tanpa melihat keterkaitan di antara unsur tersebut. Analisis wacana dalam lapangan psikologi sosial diartikan sebagai pembicaraan. Wacana yang dimaksud di sini mirip dengan struktur dan bentuk wawancara dan praktik dari pemakainya. Sementara itu, dalam lapangan politik, analisis wacana adalah praktik pemakaian bahasa karena bahasa adalah 
Umi Halwati: Analisis Teun A. Van Djik dalam Kajian Wacana Teks Dakwah ...

aspek sentral dari penggambaran suatu subjek, dan lewat bahasa ideologi terserap di dalamnya.

Karakteristik analisis wacana kritis, antara lain: ${ }^{17}$

a. Tindakan. Wacana adalah bentuk interaksi. Oleh karena itu, wacana harus dipandang sebagai sesuatu yang bertujuan (membujuk, menyangkal, bereaksi, dan lain-lain). Di samping itu wacana dipahami sebagai sesuatu yang diekspresikan secara sadar, terkontrol, bukan di luar kendali.

b. Konteks. Wacana diproduksi, dimengerti, dan dianalisis pada konteks tertentu, mempertimbangkan konteks dari wacana, seperti latar, situasi, peristiwa dan kondisi.

c. Historis. Sisi historis perlu dikembangkan untuk mendapatkan pemahaman mengenai wacana teks.

d. Kekuasaan. Setiap wacana yang muncul dalam bentuk teks, percakapan atau apapun tidak dipandang sebagai sesuatu yang alamiah, wajar dan netral, tetapi merupakan bentuk pertarungan kekuasaan.

e. Ideologi. Ideologi tidak bisa lepas dalam pembentukan wacana, yang pengaruhnya terlihat dalam wujud teks, percakapan dan lainnya.

\section{Analisis Wacana sebagai Metode Penelitian}

\section{a. Urgensi Mengkaji Teks}

Ketika seseorang membaca dan memahami teks, secara tidak langsung ia memproduksi ulang dan menafsirkan teks sesuai dengan kemampuan dan subjektivitasnya. Sebuah teks yang sama, ketika dibaca ulang bisa melahirkan pemahaman baru. Setiap pengarang teks dan pembaca tidak bisa lepas dari konteks sosial politik, psikologis, teologis, dan konteks lainnya dalam ruang dan waktu tertentu sehingga dalam memahami teks diperlukan transfer makna.

Dalam konsep filologi, bahasa dipandang sebagai lapis awal dari karya tulisan. Pengetahuan kebahasaan secara luas diperlukan untuk membedah kandungan isi karya tulisan. Melalui kajian terhadap teks, maka hasil budaya dapat diungkap. ${ }^{18}$

Wacana (discourse) dalam konsep Foucault adalah artikulasi ideologis dari kenyataan yang dibentuk oleh kelompok-kelompok yang saling berkompetisi untuk memperebutkan kebenaran tafsir sejarah, termasuk di dalamnya wacana agama. Oleh karena itu, wacana adalah kontruksi ideologis (ideological contruction) yang dipakai untuk melegitimasi, mempertahankan dan memperebutkan kekuasaan. Dalam pemikiran ini, ditegaskan bahwa pemikiran keagamaan adalah discourse, yaitu konstruksi 
ideologis untuk melegitimasi dan mempertahankan dominasi secara sosial, politik, maupun ekonomi.

\section{b. Analisis VanDjiksebagai SalahSatuMetodeMembedah Teks Dakwah}

1) Analisis Teks

Van Djik melihat suatu teks terdiri atas beberapa struktur atau tingkatan yang masing-masing bagian saling mendukung. Pertama, struktur makro, merupakan makna global atau umum dari suatu teks yang dapat diamati dengan melihat topik atau tema teks. Kedua, superstruktur, yaitu struktur wacana yang berhubungan dengan kerangka suatu teks, seperi bagian pendahuluan, isi, penutup dan kesimpulan. Pada wilayah ini dianalisis bagian-bagian teks tersusun dalam secara utuh. Ketiga, struktur mikro, yaitu makna lokal dari suatu teks yang dapat diamati dari pilihan kata, kalimat dan gaya yang dipakai oleh satu teks. ${ }^{19}$ Satu persatu elemen wacana Van Djik dalam analisis teks dapat dilihat dalam tabel berikut.

\begin{tabular}{|c|c|c|}
\hline STRUKTUR WACANA & HAL YANG DIAMATI & ELEMEN \\
\hline Struktur makro & $\begin{array}{c}\text { Tematik } \\
\text { Tema/topik yang } \\
\text { dikedepankan dalam suatu } \\
\text { teks }\end{array}$ & Topik \\
\hline Superstruktur & $\begin{array}{l}\text { Skematik } \\
\text { Bagaimana bagian dan unutan } \\
\text { teks diskemakan }\end{array}$ & Skema \\
\hline struktur mikkro & $\begin{array}{c}\text { Semantik } \\
\text { Makna yang ingin ditekankan } \\
\text { dalam teks }\end{array}$ & $\begin{array}{l}\text { Latar, detil, maksud, pra } \\
\text { anggapan, nominalisas }\end{array}$ \\
\hline struktur mikro & $\begin{array}{c}\text { Sintaksis } \\
\text { Bagaimana kalimat (bentuk, } \\
\text { stusunan) yang dipili }\end{array}$ & $\begin{array}{l}\text { Gentuk kalimat, koherensi, } \\
\text { kata gantl }\end{array}$ \\
\hline Struktur mikro & $\begin{array}{l}\text { Stilistik } \\
\text { Bagaimana pilthan kata yang } \\
\text { dipakai dalam teks }\end{array}$ & Leksikon \\
\hline Struktur mikro & $\begin{array}{l}\text { Retoris } \\
\text { Bagaimana penekanan } \\
\text { difakukan }\end{array}$ & Grafis, metafora, ekspresi \\
\hline
\end{tabular}

Sumber: Eryanto (2001), hal. 228-229.

\section{2) Kognisi Sosial}

Van Djik menawarkan analisis kognisi sosial untuk mengetahui teks diproduksi, dan kesadaran mental wartawan atau penulis yang membentuk teks. Untuk membongkar makna yang tersembunyi dari teks dibutuhkan analisis kognisi sosial. Pendekatan kognitif didasarkan pada asumsi bahwa teks tidak mempunyai makna, tetapi makna itu diberikan oleh pemakai bahasa (wartawan atau penulis). Wartawan atau penulis tidak dianggap 
sebagai individu yang netral, tetapi individu yang mempunyai bermacam nilai, pengalaman, dan pengaruh ideologi. ${ }^{20}$

Apabila suatu teks mempunyai kecenderungan tertentu, umumnya karena model wartawan atau penulis yang menggambarkan struktur kognisi wartawan atau penulis memiliki kecenderungan tertentu ketika memandang suatu peristiwa. Oleh karena itu, menurut Van Djik, analisis wacana harus menyertakan reproduksi kepercayaan yang menjadi landasan bagaimana penulis atau wartawan menciptakan suatu teks.

Ada beberapa skema yang dapat digambarkan sebagai berikut. ${ }^{21}$ Pertama, skema person menggambarkan seseorang memandang orang lain. Skema ini berhubungan dengan diri sendiri dipandang, dipahami dan digambarkan oleh seseorang. Kedua, skema peran berhubungan dengan bagaimana seseorang memandang dan menggambarkan peranan dan posisi yang ditempati di masyarakat. Ketiga, skema peristiwa berhubungan dengan yang dilihat, didengar dan peristiwa yang lalu lalang.

3) Analisis Sosial

Dimensi ketiga dari analisis Van Djik adalah analisis sosial. Wacana adalah bagian dari wacana yang berkembang di masyarakat. Oleh karena itu, untuk meneliti teks perlu dilakukan analisis intertekstual dengan meneliti wacana tentang suatu hal diproduksi dan dikonstruksi dalam masyarakat. Menurut Van Djik, mengenai masyarakat ada dua hal yang penting yaitu kekuasaan (power) dan akses (acces). ${ }^{22}$

a) Kekuasaan. Van Djik mendefinisikan kekuasaan sebagai kepemilikan yang dimiliki oleh suatu kelompok untuk mengontrol kelompok lain. Kekuasaan juga berbentuk persuasif, yakni tindakan seseorang untuk secara tidak langsung mengontrol dengan jalan mempengaruhi kondisi mental seperti kepercayaan, sikap, dan pengetahuan.

b) Akses. Van Djik memberikan perhatian pada akses di antara masing-masing kelompok dalam masyarakat. Kelompok elit memiliki akses yang lebih besar dibanding kelompok yang tidak berkuasa. Oleh karena itu, yang berkuasa mempunyai kesempatan lebih besar untuk mempunyai akses pada media dan mempunyai kesempatan yang lebih besar untuk mempengaruhi kesadaran khalayak. 
Kerangka analisis Van Djik ${ }^{23}$

\begin{tabular}{|c|c|}
\hline STRUKTUR & METODE \\
\hline $\begin{array}{l}\text { Teks } \\
\text { Menganalisis bagaimana strategi wacana } \\
\text { yang dipakal untuk menggambarkan } \\
\text { seseorang atau peristiwa tertentu, bagamana } \\
\text { tekstual yang dipa kai untuk menyingkirkan } \\
\text { atau memarjinalkan suatu kelompok } \\
\text { gagasan, atau peristiwa tertentu }\end{array}$ & critical linguistics \\
\hline $\begin{array}{c}\text { Kognisi sosial } \\
\text { Menganalisis bagaimana kognisi } \\
\text { penulis/wartawan dalam memahami } \\
\text { seseorang atau peristiwa tertentu yang akan } \\
\text { dituls } \\
\text { Analsis sosial } \\
\text { Menganalisis bagaimana wacana yang } \\
\text { berkembang dalam masyarakat, proses } \\
\text { produks dan reproduks seseorang atau } \\
\text { peristiwa digambarkan. }\end{array}$ & Studi pustaka, penelusuran sejarah \\
\hline
\end{tabular}

\section{PENU'TUP}

Media massa merupakan saluran atau mediator bagi publikasi ideologi sehingga menjadi efektif dalam perang wacana melalui ekspresi-ekspresi yang ditunjukkan dalam teks. Di samping itu, media massa memiliki peran aktif sebagai penyalur informasi dan melakukan intervensi terhadap teks dakwah. Media massa masih dipandang sebagai media yang efektif sebagai sarana dakwah. Oleh karena itu, analisis wacana perlu dikembangkan pada masalah-masalah keberagamaan di Indonesia.

\section{ENDNOTES}

1 Eriyanto, Analisis Wacana Pengantar Analisis Teks Media (Yogyakarta: LKiS, 2005), cet ke-4, hal. 13.

${ }^{2}$ Alex Sobur, Analisis Teks Media: Suatu Pengantar untuk Analisis Wacana, Analisis Semiotik, dan Analisis Framing (Bandung: Remaja Rosdakarya, 2001), hal. 3.

3 Ibid., hal. 66.

4 Ibid.

5 Ibid., hal. 71.

${ }^{6}$ Nurudin, Komunikasi Massa (Malang: Cespur, 2003), hal. 214-223.

${ }^{7}$ Faizah Nur Laila, “Analisis Wacana Kritis dalam Studi Teks Dakwah”, Jurnal IImu Dakwah, Vol. 11. No.1, April 2005, hal. 79.

${ }^{8}$ Komarudin Hidayat, Menafsirkan Kehendak Tuhan (Bandung: Teraju, 2004), hal. 22. 
Umi Halwati: Analisis Teun A. Van Djik dalam Kajian Wacana Teks Dakwah ...

9 Deddy Mulyana, Komunikasi Efektif Perspektif Komunikasi Antar Budaya (Bandung: Rosdakarya, 2004), hal. 15-16.

10 Ibid., hal. 14.

${ }^{11}$ Eriyanto, Analisis Wacana, hal. 2.

12 Ibid., hal. 9.

${ }^{13}$ Eko Wijayanto, Teori-teori Diskursus (Bandung: Teraji-Mizan, 2005), hal. xvii.

${ }^{14}$ Faizah Nur Laila, "Analisis Wacana, hal. 79.

${ }^{15}$ Eriyanto, Analisis Wacana, hal. 2.

${ }^{16}$ Ibid., hal. 1-3.

17 Ibid., hal. 15-17.

${ }^{18}$ Muhamad Walidin, "Pendekatan Filologi dalam Studi Islam". Makalah, Fakultas Adab UIN Yogyakarta, 2008.

${ }^{19}$ Eryanto, Analisis Wacana, hal. 225-227.

${ }^{20}$ Ibid., hal. 260-261.

21 Ibid., hal. 262-263.

22 Ibid., hal. 271-272.

${ }^{23}$ Ibid., hal. 275.

\section{DAFTAR PUSTAKA}

Eriyanto. 2005. Analisis Wacana Pengantar Analisis Teks Media. Yogyakarta: LKiS. Foucault, Michel. 1994. The Order of Things: Archeology of the Human Sciences. New York: Vintage Books.

2002. Archeology of Knowledge. Terj. Moehtar Zoerni. Arkeologi Pengetahuan. Yogyakarta: Qalam.

2002. Pengetahuan dan Metode: Karya Penting Foucault.

Yogyakarta: Jalasutra.

Hidayat, Komarudin. 2004. Menafsirkan Kehendak Tuhan. Bandung: Teraju.

Mulyana, Deddy. 2004. Komunikasi Efektif Perspektif Komunikasi Antar Budaya. Bandung: Rosdakarya.

Nur Laila, Faizah. "Analisis Wacana Kritis dalam Studi Teks Dakwah" dalam Jurnal IImu Dakwah, Vol. 11. No.1, April 2005. IAIN Sunan Ampel Surabaya.

Nurudin. 2003. Komunikasi Massa. Malang: Cespur.

Sobur, Alex. 2001. Analisis Teks Media: Suatu Pengantar untuk Analisis Wacana, Analisis Semiotik, dan Analisis Framing. Bandung: Remaja Rosdakarya.

Walidin, Muhamad 2008. "Pendekatan Filologi dalam Studi Islam" dalam Makalah, Fakultas Adab UIN Yogyakarta.

Wijayanto, Eko. 2005. Teori-teori Diskursus. Bandung: Teraju-Mizan. 